\title{
Understanding kinetics and mechanisms of pyroxenes weathering
}

LUIS MONASTERIO-GUILLOT ${ }^{1}$, ENCARNACIÓN RUIZAGUDO $^{2}$ AND CARLOS RODRÍGUEZ-NAVARRO ${ }^{3}$

${ }^{1}$ Universidad de Granada

${ }^{2}$ University of Granada (Spain)

${ }^{3}$ University of Granada

Presenting Author: luismonasterio@ugr.es

Pyroxenes are principal constituents of many ultramafic and basic rocks and therefore, are main minerals in the Earth's crust. Weathering of these minerals has an important impact in several biogeochemical processes (e.g., solute release, nutrients supply) including the $\mathrm{C}$ cycle (e.g., $\mathrm{CO}_{2}$ mineral capture). In this context, acidic weathering of piroxenes occurs in a wide range of scenarios (e.g., acid mine drainage, volcanic environments, acid rain, $\mathrm{CO}_{2}$ geological storage -GCS-). Understanding the kinetics that govern the weathering of these minerals is crucial to optimize carbonation reaction in GCS strategies or the conditions for hosting life in other planets (Mars). However, relatively few studies have been performed to unravel the dissolution mechanisms and kinetics of these minerals, as compared to other silicates, such as feldspars or olivine.

In this study, we performed far-from-equilibrium dissolution experiments of single crystals of augite $\left(\left(\mathrm{Ca}, \mathrm{Mg}, \mathrm{Fe}^{2+}\right)_{2} \mathrm{Si}_{2} \mathrm{O}_{6}\right)$ and diopside $\left(\mathrm{CaMgSi}_{2} \mathrm{O}_{6}\right)$ in acidic conditions $(\mathrm{pH}$ 1.5) and $80^{\circ} \mathrm{C}$ under batch and flow-through conditions during $10 \mathrm{~h}$. Afterwards, crystals and solutions were separeted, collected and analyzed by means of SEM, HRTEM, FTIR, $\mu$-CT and ICPOES.

Our results showed the formation of etch pits and cracks by stress corrosion and pressure exerted by an amorphous silica gel phase, precipitated despite the bulk solution being undersaturation with respect to this phase. These precipitates were localized in etch pits and cracks revealing that supersaturation can be reached locally. Cracks formation and amorphous silica precipitates were more abundant in augite as compared to diopside due to the higher iron content. Finally, magnesium silicate hydrate precursor phase was formed during diopside dissolution experiments, evidencing local alkaline $\mathrm{pH}$ despite the acidic conditions of the bulk solution.

This study reveal the importance of mineral chemistry on geological carbon storage strategies (e.g., $\mathrm{Na}, \mathrm{Fe}, \mathrm{Al}$ ) and the relevance of Interface-Coupled Dissolution-Precipitation mechanisms on the formation of amourphous silica precipitated. 